\title{
Non-NMDA Receptor-Mediated Neurotoxicity in Cortical Culture
}

\author{
Jae-Young Koh, Mark P. Goldberg, Dean M. Hartley, and Dennis W. Choi \\ Department of Neurology, Stanford University Medical School, Stanford, California 94305
}

The neurotoxicity of 3 non-NMDA glutamate receptor agonists-kainate, $\alpha$-amino-3-hydroxy-5-methyl-4-isoxazolepropionate (AMPA), and quisqualate-was investigated quantitatively in dissociated murine cortical cultures. Five minute exposure to $500 \mu \mathrm{M}$ kainate, but not AMPA, produced widespread acute neuronal swelling. Kainate-induced swelling was resistant to 2-amino-5-phosphonovalerate (APV) or replacement of extracellular sodium with choline but attenuated by either kynurenate or low concentrations of quisqualate. Unlike NMDA agonists, kainate or AMPA did not produce much late neuronal loss after a 5 min exposure.

In contrast, $5 \mathrm{~min}$ exposure to $500 \mu \mathrm{M}$ quisqualate produced both acute neuronal swelling and widespread late neuronal degeneration. This acute swelling was blocked by APV or by replacement of extracellular sodium by choline, consistent with mediation by NMDA receptors; we speculate that high concentrations of quisqualate may directly activate NMDA receptors or induce the release of endogenous glutamate. Quisqualate-induced late neuronal degeneration may be due to another unexpected process: cellular quisqualate uptake and delayed release, converting brief addition into prolonged exposure. Hours after thorough washout of exogenously added quisqualate, micromolar concentrations could be detected in the bathing medium by high performance liquid chromatography.

With lengthy exposure (20-24 hr), all 3 non-NMDA agonists were potent neurotoxins, able to destroy neurons with $\mathrm{EC}_{50}$ 's of about $20 \mu \mathrm{M}$ for kainate, $4 \mu \mathrm{M}$ for AMPA, and $1 \mu \mathrm{M}$ for quisqualate. Kynurenate and 6-cyano-7-nitroquinoxaline-2,3dione (CNQX), but not APV or L-glutamate diethyl ester, were effective in attenuating the neuronal degeneration induced by these agonists. CNQX was about 3 times more selective than kynurenate against kainate-induced neuronal injury, but CNQX was still nearly equipotent with APV against NMDAinduced injury. Gamma-D-glutamylaminomethyl sulfonate exhibited partial antagonist specificity for AMPA-induced toxicity.

The neuroexcitatory and neurotoxic effects of the amino acid neurotransmitter glutamate are mediated by several types of postsynaptic receptors, commonly referred to by the preferred agonists NMDA, kainate, and quisqualate (Foster and Fagg, 1984; Watkins and Olverman, 1987). More recently, it has become apparent that quisqualate activates 2 types of receptors:

Received June 30, 1989; revised Aug. 28, 1989; accepted Aug. 30, 1989.

We thank K. Rose for expert assistance with cell cultures. This research was supported by NIH grants NS12151 and NS26907.

Correspondence should be addressed to Dennis W. Choi, Department of Neurology H-3160, Stanford University Medical School, Stanford, CA 94305.

Copyright (C) 1990 Society for Neuroscience $0270-6474 / 90 / 100693-13 \$ 02.00 / 0$ one selectively activated by the agonist $\alpha$-amino-3-hydroxy-5methyl-4-isoxazolepropionate (AMPA) and directly opening a membrane ionophore (the AMPA/quisqualate receptor) (Krogsgaard-Larsen et al., 1980; Honoré et al., 1982); the other acting via G-proteins to activate phospholipase C (the "metabotropic" quisqualate receptor) (Sladeczek et al., 1985; Nicoletti et al., 1986; Sugiyama et al., 1987; see also Eccles and McGeer, 1979).

Kainate and AMPA/quisqualate receptors, which probably mediate most fast excitatory synaptic transmission in the CNS (Mayer and Westbrook, 1987), mediate a majority share of both glutamate neuroexcitation and glutamate-induced acute neuronal swelling in cortical cultures (Choi et al., 1988). However, NMDA receptors may critically mediate the eventual neuronal degeneration induced by brief glutamate exposure (Choi et al., 1988). In part, this may be due to the high affinity of glutamate for NMDA receptors (Olverman et al., 1984). In addition, NMDA receptors alone open membrane channels with high calcium permeability (MacDermott et al., 1986), and thus may dircctly trigger a toxic influx of extracellular calcium (Choi, 1987). Consistent with key involvement of NMDA receptors in glutamate neurotoxicity, selective NMDA antagonists reduce the neuronal injury associated with several types of insults (Rothman and Olney, 1987; Choi, 1988), including ischemia (Simon et al., 1984), hypoglycemia (Wieloch, 1985), hypoxia (Weiss et al., 1986), and trauma (Faden and Simon, 1988).

Nonetheless, extensive data obtained both in vivo and in vitro suggest that excess stimulation of non-NMDA receptors can suffice to destroy neurons (Coyle et al., 1981; Rothman and Olney, 1987; Frandsen et al., 1989; Mattson et al., 1989). The contribution of non-NMDA receptors to acute glutamate neurotoxicity may be relatively minor, at least on most mature cortical or hippocampal neurons, but these receptors could be important under other conditions-for example, in other brain regions, during chronic neurotoxic exposure, or during exposure to selective non-NMD $\wedge$ agonists. Indeed, certain neuronal subpopulations may be more vulnerable to injury mediated by non-NMDA receptors than by NMDA receptors. Neurons containing high concentrations of the enzyme NADPH-diaphorase represent one such population in neocortex (Koh et al., 1986; Koh and Choi, 1988b) or striatum (Koh and Choi, 1988a).

Although no selective non-NMDA agonist endogenous to the CNS has yet been found, it is possible that the co-release of $\mathrm{Zn}^{2+}$ with glutamate could approximate such an agonist (Peters et al., 1987; Koh and Choi, 1988c). Alternatively, a non-NMDA agonist could be supplied exogenously; ingestion of the plant nonNMDA receptor agonist, $\beta$ - $N$-oxalylamino-L-alanine (BOAA) causes lathyrism, a chronic neurodegenerative disease affecting motoneurons (Olney et al., 1976; MacDonald and Morris, 1984; Spencer et al., 1986). Selective damage to motoneurons in monkeys and possibly in man (Guam amyotrophic lateral sclerosis- 
Parkinsonism-dementia) may be induced by ingestion of the related compound, $\beta$ - $N$-methylamino-L-alanine (BMAA) (Spencer et al., 1987). While millimolar concentrations of BMAA clearly activate NMDA receptors, it is possible that the lower concentrations may preferentially activate non-NMDA receptors (Weiss et al., 1989b). Observations with these plant amino acid toxins raise the possibility that non-NMDA receptors may participate in the pathogenesis of certain sporadic neurodegenerative diseases, for example, the sporadic form of amyotrophic lateral sclerosis, or even Alzheimer's disease (Choi, 1989; Greenamyre and Young, 1989).

There is at present little quantitative data relevant to nonNMDA receptor-mediated neurotoxicity at the cell level. In the present study, we characterized the neurotoxicity of the 3 prototypical non-NMDA agonists-kainate, quisqualate, and AMPA - on cultured murine cortical neurons, using approaches previously used to study the neurotoxicity of glutamate in the same system (Choi et al., 1987). An abstract has appeared (Koh et al., 1988).

\section{Materials and Methods}

Cortical cell cultures. Mixed cortical cell cultures, containing both neuronal and glial elements, were prepared as previously described (Choi et al., 1987) from fetal mice at 14-17 d gestation. Dissociated cortical cells were plated in Primaria (Falcon) $15 \mathrm{~mm}$ multiwell vessels (about $0.4 \times 10^{\circ} \mathrm{cells} /$ well) in Eagle's minimal essential medium (MEM, Earle's salts) supplemented with $10 \%$ heat-inactivated horse serum, $10 \%$ fetal bovine serum, glutamine ( $2 \mathrm{~mm})$, and glucose (10-20 mM). Cultures were kept at $37^{\circ} \mathrm{C}$ in a humidified $\mathrm{CO}_{2}$-containing incubator (initial $\mathrm{pH}$ 7.4). After 5-10 d in vitro, non-neuronal cell division was halted by $1-$ $3 \mathrm{~d}$ of exposure to $10^{-5} \mathrm{M}$ cytosine arabinoside, and the cells were shifted into a maintenance medium identical to the plating media, but lacking fetal serum. Subsequent media replacement was carried out twice per week. Only mature (14-24 d in vitro) cortical cultures were selected for study; key comparisons were made on sister cultures derived from a single plating.

Exposure to excitatory amino acids. Exposure to excitatory amino acids was via the bathing medium, utilizing defined solutions lacking serum, glutamate, or lactate dehydrogenase. Care was taken to wash out the normal medium from cultures prior to addition of excitatory amino acid exposure solutions. One of two different exposure protocols was selected depending on exposure length. Long exposures (>30 min) were carried out in the culture incubator, using a defined medium consisting of MEM supplemented only with glucose (total, $25 \mathrm{~mm}$ ). In control experiments, this simplified culture medium was well tolerated by cortical cell cultures for several days.

Brief exposure to excitatory amino acids ( $30 \mathrm{~min}$ or less) was carried out in room air, using a Tris-buffered salt solution with the following composition (in mM): $\mathrm{NaCl} 120 ; \mathrm{KCl} 5.4 ; \mathrm{MgCl}_{2} 0.8 ; \mathrm{CaCl}_{2} 1.8$; Tris$\mathrm{Cl}\left(\mathrm{pH} 7.6\right.$ at $\left.25^{\circ} \mathrm{C}\right), 25$; glucose 15 . Exposure was terminated by washing out the exposure solution thoroughly and replacing it with MEM plus glucose $(25 \mathrm{~mm})$, prior to relurning the dishes to the $37^{\circ} \mathrm{C}$ incubator. Little or no cortical cell damage was produced by this protocol if excitatory amino acids were omitted.

NADPH-diaphorase histochemistry. Staining for NADPH-diaphorase was carried out on fixed cultures (30 min in 4\% paraformaldehyde at room temperature) (Scherer-Singler et al., 1983). Cultures were incubated in medium containing $1 \mathrm{~mm}$ NADPH (Sigma) and $0.2 \mathrm{~mm}$ nitroblue tetrazolium in $0.1 \mathrm{M}$ Tris buffer $(\mathrm{pH} 8.2)$ at $37^{\circ} \mathrm{C}$ for $30 \mathrm{~min}$ to $1 \mathrm{hr}$. The staining reaction was terminated by washing with water.

Assessment of neuronal injury. Overall neuronal cell injury was estimated in all experiments by examination of cultures with phase-contrast microscopy at 100-400 $\times$. This examination was usually performed $1 \mathrm{~d}$ after excitatory amino acid exposure, at which point the process of cell death was largely complete; previous experience has suggested that the excilatory amino acid-induced injury of cultured cortical neurons and glia can reliably be estimated in this fashion. In some experiments, this examination was verified by subsequent bright-field examination of trypan blue staining $(0.4 \%$ for $5 \mathrm{~min})$, a dye staining debris and nonviable cells.
In most experiments, overall neuronal cell injury was also quantitatively assessed by the measurement of lactate dehydrogenase (LDH), released by damaged or destroyed cells, in the extracellular fluid $1 \mathrm{~d}$ after excitatory amino acid exposure (Koh and Choi, 1987). A small amount of LDH was always present in the media of cultures carried though the exposure protocol but without addition of excitatory amino acids. This background amount, determined on sister cultures within each experiment, was subtracted from values obtained in treated cultures. Control experiments showed that the specific efflux of LDH induced by glutamate ex posure (after background subtraction) was lincarly proportional to the number of neurons damaged or destroyed and that no specific LDH efflux occurred when pure cultures of cortical glia were similarly exposed to glutamate (Koh and Choi, 1987).

The absolute value of the LDH efflux produced by a given excitatory amino acid exposure was quite consistent within sister cultures of a single plating, but differed somewhat between platings, largely as a function of neuronal density (which varied despite constant original plating densities, presumably reflecting small variations in cell preparation or serum characteristics). Therefore, each observed LDH value was scaled to the mean value produced by exposure to high concentrations of some specified excitatory amino acid in other sister cultures.

Staining of cultures for NADPH-diaphorase unequivocally labeled a small, scattered subpopulation of neurons, making it feasible to simply count the total number of labeled neurons in each well (40-200 ncurons in control wells) using low-power $(100 \times)$ bright-field optics and confirmatory high-power $(400 \times)$ examination as necessary. Damage to the NADPH-diaphorase-containing neuronal subpopulation was measured as the difference between the mean number of cells in several untreated control wells and the mean number of cells in experimental cultures, expressed as a percentage of the former.

Calculation for $\mathrm{pA}_{2} . p A_{2}$ values for kynurenate were estimated with the following equation (Arunlakshana and Schild, 1959):

$$
p A_{2}=-\log ([\text { kynurenate }])+\log \left(\mathrm{EC}_{50-\mathrm{kyn}} / \mathrm{EC}_{50 \text {-crl }}-1\right),
$$

where $\mathrm{EC}_{50-\mathrm{kyn}}$ is the agonist concentration that produces half-maximal LDH release in the presence of kynurenate, and $\mathrm{EC}_{50-\mathrm{ctrl}}$ is the agonist concentration that produces half-maximal LDH release without kynurenate. $\mathrm{EC}_{50}$ values were estimated from observed concentration-toxicity data.

High performance liquid chromatography. Excitatory amino acid concentrations in media samples were determined by reverse-phase highperformance liquid chromatography (HPLC), using fluorescence detecticn (Lindroth and Mopper, 1979) and gradient conditions as described by Connick and Stone $(1988)$. Sample aliquots $(50 \mu \mathrm{l})$ were mixed with $100, \mu l o$-phthaldialdehyde (OPT)/2-mercaptoethanol reagent (Sigma). After $1 \mathrm{~min}, 100 \mu \mathrm{l}$ of this mixture was injected onto the analytic column (C18 $\mu$-Bondapak column fitted with C18 precolumn, Waters). Phosphate buffer ( $\mathrm{pH} 7.2)$ : water : acetonitrile (solvent $\mathrm{A}$ ) and water : acetonitrile: methanol (solvent B) were prepared using HPLC-grade reagents, and eluted in the following gradient program (\% solvent $\mathrm{B}$ ): 0 $\min (0), 2 \mathrm{~min}(0), 12 \mathrm{~min}(100)$. The flow rate was $1.5 \mathrm{ml} / \mathrm{min}$.

OPT derivatives of aspartate, glutamate, and quisqualate were identified by their retention times, and concentrations quantified by peak height comparisons to an amino acid standard solution containing 40 amino acids (Sigma) and quisqualate $(2.5 \mu \mathrm{M})$.

Control experiments showed that this HPLC procedure could resolve aspartate, glutamate, and quisqualate from each other and from the 38 additional amino acid in the standard.

Drugs. AMPA, DL-2-amino-5-phosphonovalerate (APV), $\gamma$-D-glutamylaminomethyl sulfonate (GAMS), and 6-cyano-7-nitroquinoxaline2,3-dione (CNQX) were purchased from Tocris Neuramin. Quisqualate, of both natural and synthetic origin, was obtained from Cambridge Research Biochemicals. Kainate, kynurenate, L-glutamate diethyl ester (GDEE), 4,4'-diisothiocyano-2,2'-disulfonic acid (DIDS), dihydrokainate (DHK), and most other reagents, were obtained from Sigma.

\section{Results}

\section{Brief exposure to non-NMDA agonists}

Cortical cultures exposed for $5 \mathrm{~min}$ to $500 \mu \mathrm{M}$ kainate exhibited dramatic immediate swelling and darkening of neuronal cell bodies under phase-contrast microscopy; however, within an hour after kainate washout, the swelling largely abated. By the next day only a small amount of neuronal damage was evident 

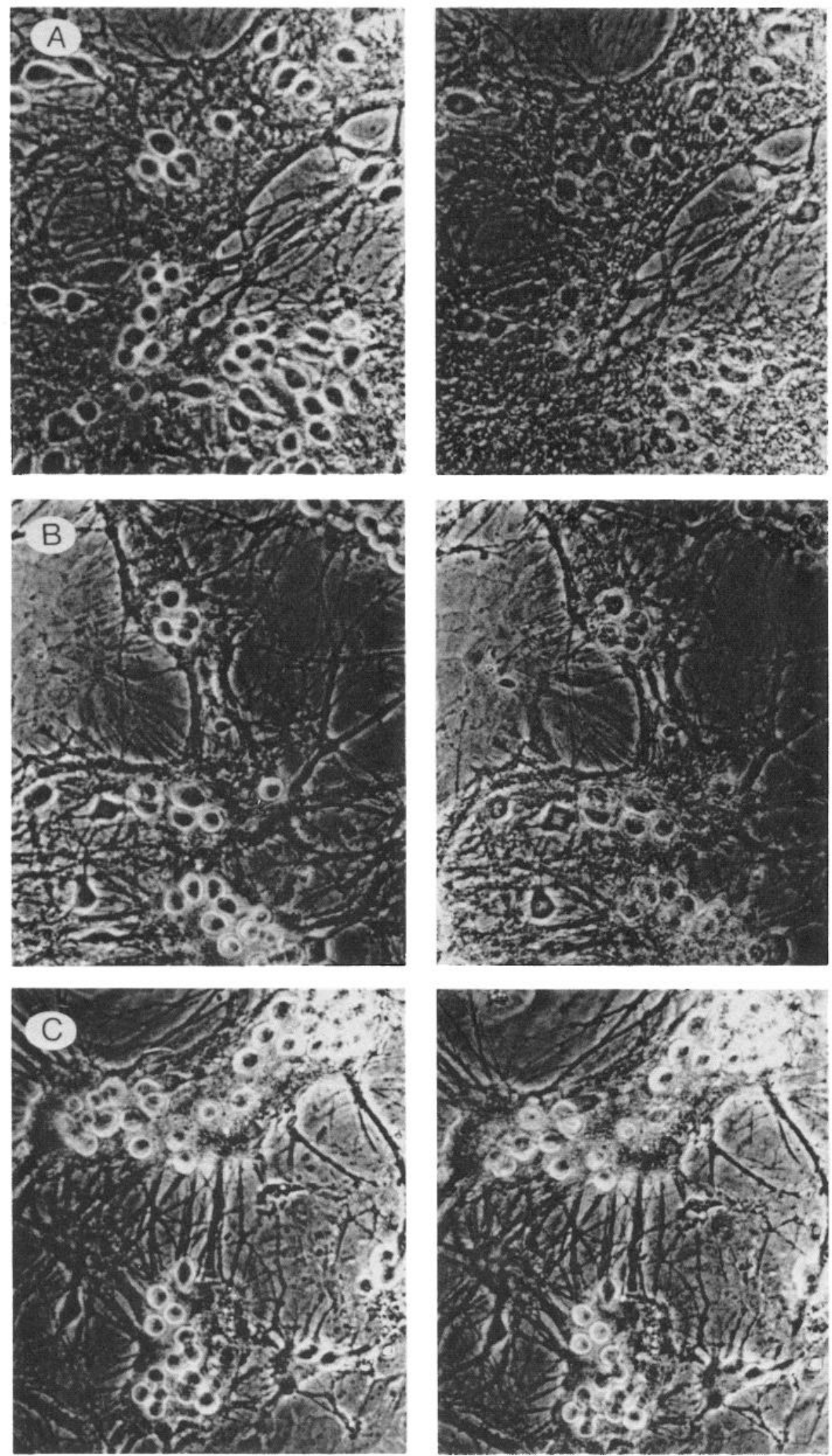
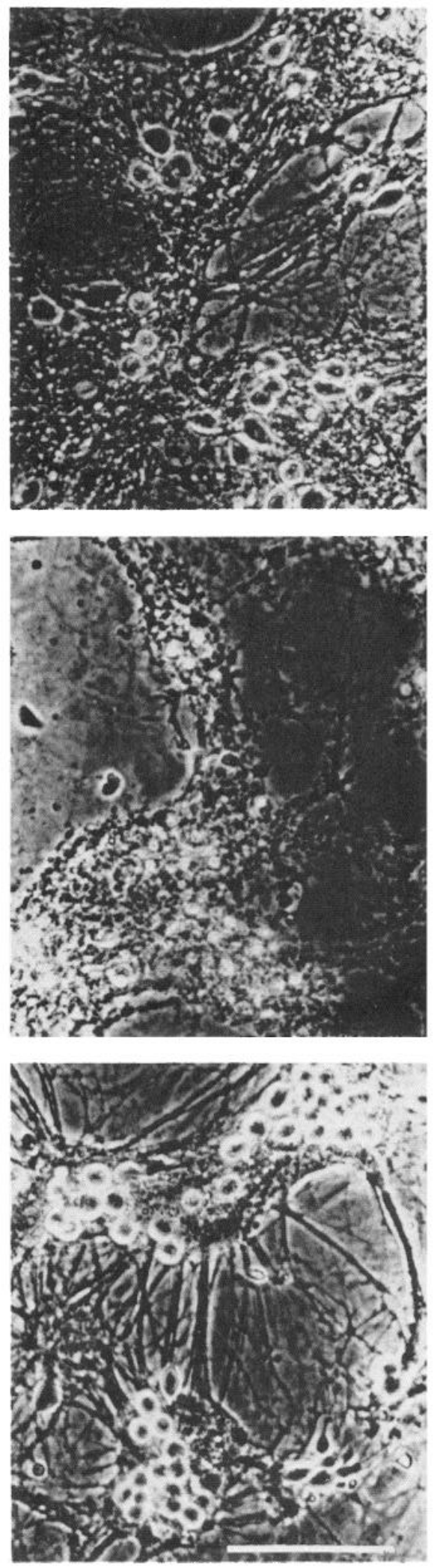

Figure 1. Morphological damage produced by brief exposure to kainate, quisqualate, and AMPA. Phase-contrast photomicrographs follow representative fields of cortical neurons in sister cultures, taken before (left column), immediately after (middle), and $20 \mathrm{hr}$ after (right) 5 min exposure to $500 \mu \mathrm{M}$ kainate $(A), 500 \mu \mathrm{M}$ quisqualate $(B)$, or $500 \mu \mathrm{M}$ AMPA $(C)$. Quisqualate produced both acute neuronal swelling and extensive late neuronal death, kainate produced only the former; AMPA produced neither. Scale bar, $100 \mu \mathrm{m}$. 


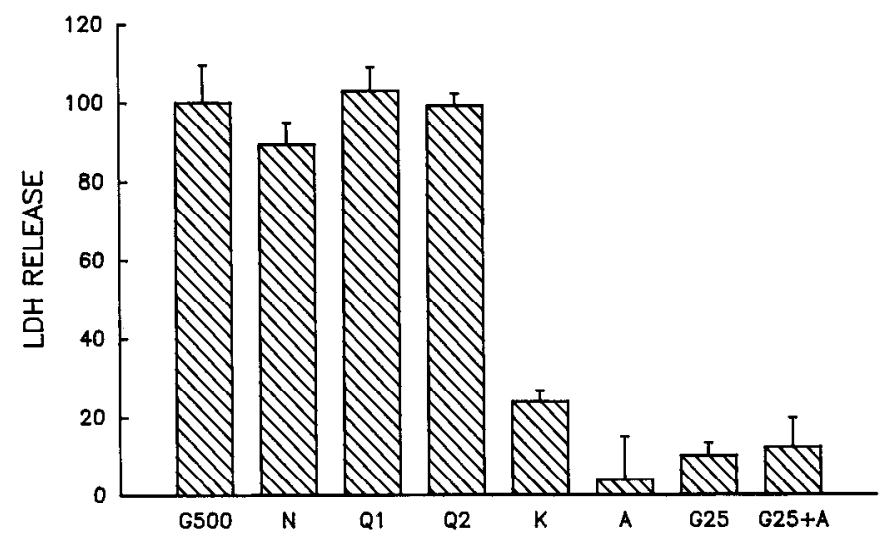

Figure 2. Chemical evidence of damage induced by non-NMDA agonists. Bars depict mean LDH ( $+\mathrm{SEM} ; n=4$ in all cases) released into the bathing media $20-24 \mathrm{hr}$ after $5 \mathrm{~min}$ exposure to $500 \mu \mathrm{M}$ concentrations of glutamate $(G 500)$, NMDA $(N)$, natural quisqualate $(Q I)$, synthetic quisqualate $(Q 2)$, kainate $(K)$, or AMPA $(A)$. Other cultures were exposcd for $5 \mathrm{~min}$ to $25 \mu \mathrm{M}$ glutamate (G25) or $25 \mu \mathrm{M}$ glutamate plus $1 \mathrm{~mm}$ AMPA $(G 25+A)$. LDH values were scaled to the mean value found in the $G 500$ condition $(=100)$. Substantial late neuronal damage was found in the cultures exposed to either natural or synthetic quisqualate; but not AMPA, kainate, or low concentrations of glutamate.

(Fig. 1A). The same brief exposure to $500 \mu \mathrm{M}$ AMPA was followed by neither much acute neuronal swelling nor late neuronal loss (Fig. 1C). Unexpectedly, exposure to quisqualate differed markedly from exposure to AMPA, producing both acute neuronal swelling (slightly less than that induced by kainate) and widespread late neuronal degeneration (Fig. $1 B$ ). In all cases, background glial cells showed little morphological change and retained the ability to exclude trypan blue.

Quantitative assessment of the late neuronal damage resulting from these exposures could be accomplished by measuring the efflux of the cytosolic enzyme LDH to the bathing medium 24 hr later. We previously showed that 5 min exposure to $500 \mu \mathrm{M}$ glutamate or NMDA (Choi et al., 1988) resulted by the next day in extensive neuronal degeneration and concomitant LDH efflux. Consistent with morphological observations, 5 min exposure to $500 \mu \mathrm{M}$ kainate or AMPA produced little LDH efflux, but $500 \mu \mathrm{M}$ quisqualate was roughly equipotent as a neurotoxin to glutamate or NMDA (Fig. 2).

We considered the possibility that the anomalous neurotoxic efficacy of brief quisqualate exposure might be due to glutamatc contamination (Cha et al., 1987). However, HPLC measurement of the glutamate level in our lot of quisqualate showed only $2 \%$ contamination. Even a contamination level as high as $5 \%$ would have resulted in a $500 \mu \mathrm{M}$ quisqualate solution containing only $25 \mu \mathrm{M}$ glutamate, a concentration too low to produce much in the way of either acute neuronal swelling (not shown) or late neuronal injury (Fig. 2). In addition, no toxic synergy was produced when $25 \mu \mathrm{M}$ glutamate was added to $1 \mathrm{~mm}$ AMPA (Fig. 2); furthermore, synthetically prepared quisqualate lacking detectable glutamate contamination possessed neurotoxicity comparable to that of natural quisqualate (Fig. 2). Further examination of the basis for the neurotoxicity of brief quisqualate exposure is presented in a separate section below.

The low neurotoxicity of both kainate and AMPA persisted even if exposure times were increased 6-fold to $30 \mathrm{~min}$. Detailed investigation of the dependence of $1 \mathrm{mM}$ AMPA toxicity upon exposure time revealed that exposure times in excess of $1 \mathrm{hr}$

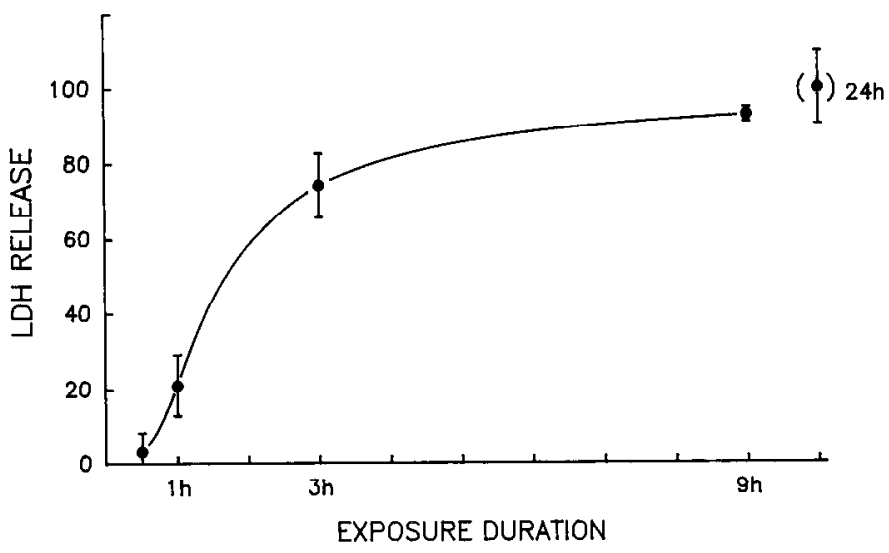

Figure 3. Time dose-response for AMPA neurotoxicity. Sister cultures were exposed to $1 \mathrm{mM}$ AMPA for the indicated time. Samples of bathing media were taken both before washout of AMPA, and $24 \mathrm{hr}$ after the initiation of exposure, and summed to obtain total released LDH (mean $\pm \mathrm{SEM}, n=4$ ), scaled to the mean value found in cultures exposed to $1 \mathrm{~mm}$ AMPA for $24 \mathrm{hr}(=100$, a value reflecting virtually complete morphological neuronal loss).

were required for reliable destruction of $>25 \%$ of the neuronal population (Fig. 3).

\section{Acute neuronal swelling}

The neuronal cell body swelling produced acutely by brief kainate or quisqualate exposurc was measured quantitatively from photomicrographs taken before and after exposure. As expected, 1 mм APV, a selective NMDA receptor antagonist, produced little reduction in kainate-induced swelling; however, $1 \mathrm{~mm}$ APV did block the acute swelling induced by quisqualate (Fig. 4). In other experiments, the same effects were seen with $500 \mu \mathrm{M}$ D-APV or with synthetic quisqualate; the latter suggested that this APV sensitivity was not explained by glutamate contamination of the quisqualate used.

Like the swelling induced by NMDA agonists (Choi et al., 1988), quisqualate-induced swelling could be blocked by substitution of choline for extracellular sodium; in fact, neurons became slightly smaller than those exposed to sham wash alone (Fig. 5) $(p<0.05,2$-tailed $t$-test). In contrast, choline substitution had little effect on kainate-induced neuronal swelling (Fig. 5). Both kainate- and quisqualate-induced swelling were blocked by the broad-spectrum antagonist kynurenate (Fig. 5).

Interestingly, a low $(10 \mu \mathrm{M})$ concentration of quisqualate could attenuate the swelling induced by kainate, whereas the reverse was not true (Fig. 5). AMPA, $500 \mu \mathrm{M}$ (which itself produced little neuronal swelling; see Fig. $1 C$ ), did not attenuate the swelling induced by either $100 \mu \mathrm{M}$ kainate or $100 \mu \mathrm{M}$ quisqualate (not shown).

\section{Prolonged exposure to non-NMDA agonists}

Extending the exposure time from $5 \mathrm{~min}$ to $20-24 \mathrm{hr}$ greatly increased the neurotoxicity of kainate, quisqualate, and AMPA. All 3 agonists then produced concentration-dependent neuronal damage and LDH efflux (Fig. 6); at high concentrations, all destroyed nearly the entire neuronal population as assessed by morphological criteria. Of the 3 , quisqualate was the most potent toxin with $\mathrm{EC}_{50}$ of about $1 \mu \mathrm{M} ; \mathrm{EC}_{50}$ 's for AMPA and kainate were about 4 and $20 \mu \mathrm{M}$, respectively. The addition of $500 \mu \mathrm{M}$ kynurenate to the exposure media shifted all 3 curves in parallel 

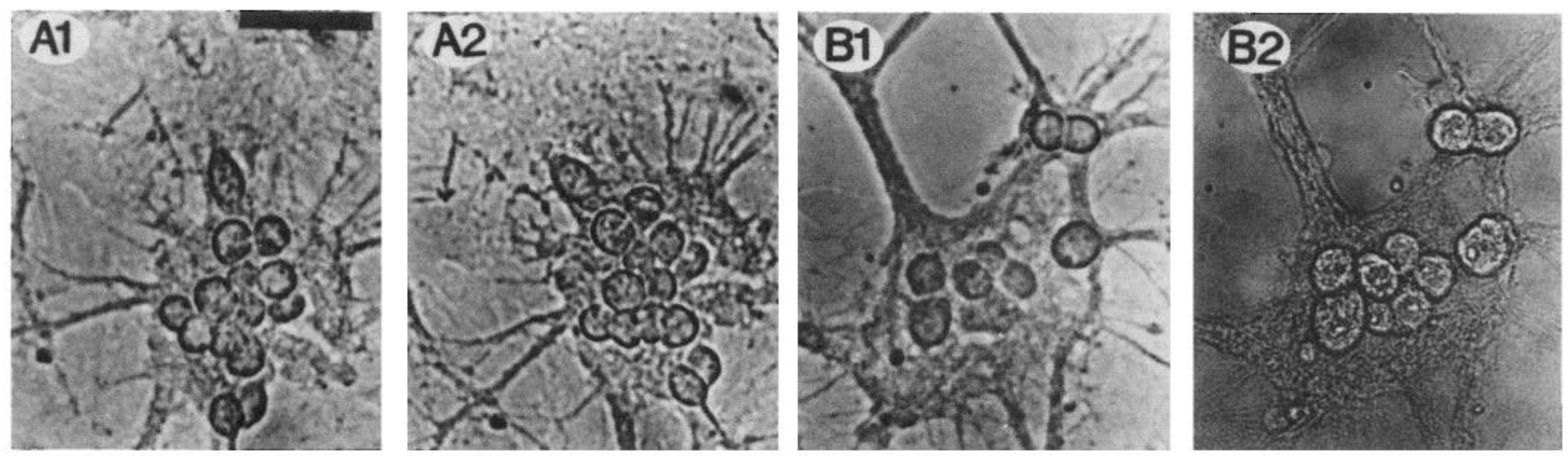

C

APV ATTENUATES QUISQUALATE-INDUCED NEURONAL SWELLING

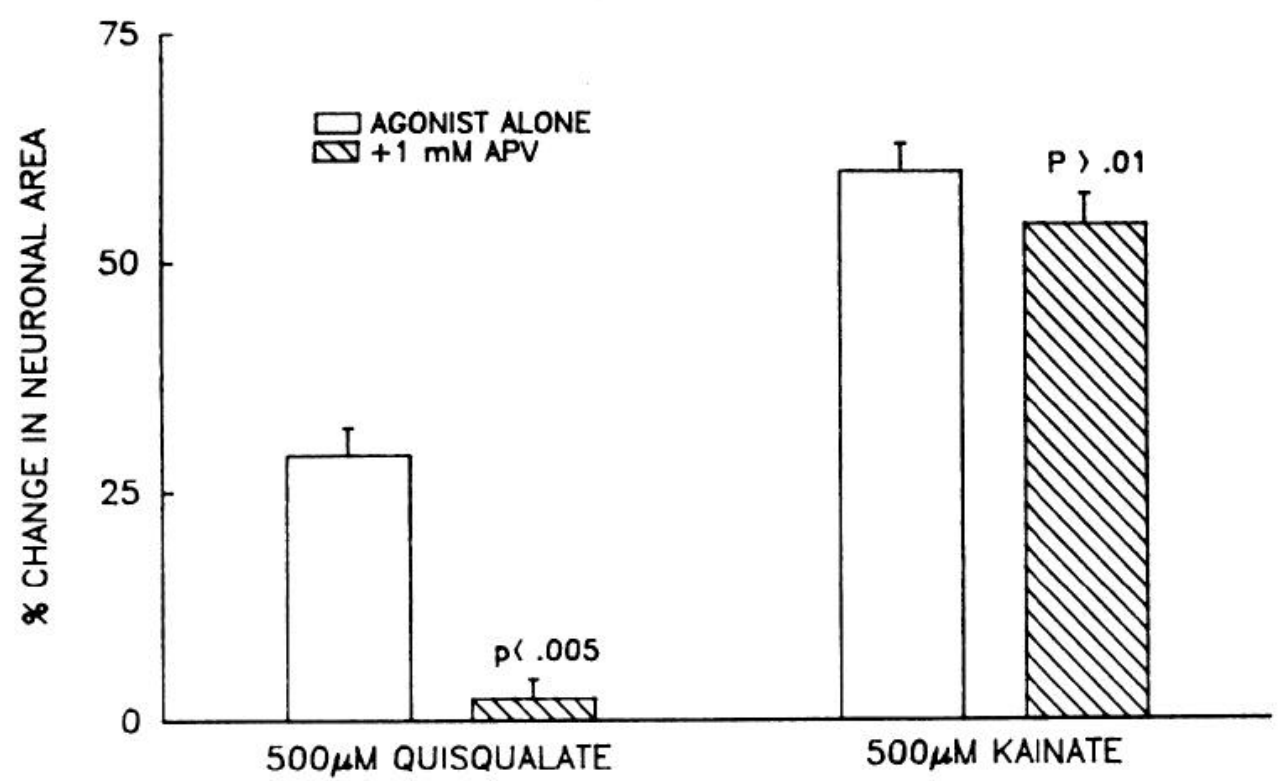

Figure 4. NMDA receptors mediate quisqualate-induced acute neuronal swelling. Bright-field photomicrographs of neurons in sister cultures before and after 20-30 min exposure to $500 \mu \mathrm{M}$ quisqualate $(A 1, A 2)$ and $500 \mu \mathrm{M}$ kainate $(B 1, B 2)$ both in the presence of $1 \mathrm{mM}$ APV. Bars in $C$ indicate mean percentage change ( $+\mathrm{SEM} ; n=36-50$ cells) in area of neuronal cell bodies in cultures exposed to quisqualate or kainate, with or without $1 \mathrm{~mm}$ APV. Neuronal cell body areas were measured directly from photomicrographs by tracing the outline with a digitizer linked to a microcomputer. APV substantially attenuated quisqualate-induced, but not kainate-induced, swelling. Scale bar, $50 \mu \mathrm{m}$. Statistical assessment of APV effect was by 2 -tailed $t$-test.

fashion to the right, producing $\mathrm{EC}_{50}$ 's of about $10 \mu \mathrm{M}$ for quisqualate, $15 \mu \mathrm{M}$ for AMPA, and $85 \mu \mathrm{M}$ for kainate. The finding that the protective effect of kynurenate could be overcome by increasing agonist concentration is consistent with competitive antagonism. Calculated $p A_{2}$ values of kynurenate were 4.1 for quisqualate, 3.7 for AMPA, and 3.8 for kainate.

Several other excitatory amino acid antagonists-APV, GAMS, GDEE, and the novel non-NMDA antagonist CNQX (Honoré et al., 1987) - were screened against the neuronal injury caused by $24 \mathrm{hr}$ exposure to $3 \mu \mathrm{M}$ quisqualate, $30 \mu \mathrm{M}$ kainate, or $10 \mu \mathrm{M}$ AMPA (Fig. 7). These agonist concentrations were chosen to induce quantitatively similar, submaximal amounts of neuronal damage (see Fig. 6). APV or GDEE, both $500 \mu \mathrm{M}$, produced little protective effect. GAMS, $500 \mu \mathrm{M}$, significantly reduced AMPA toxicity but had little effect on kainate or quis- qualate toxicity. Partial (about 30\%) reduction of kainate or quisqualate toxicity was seen with $1 \mathrm{~mm}$ GAMS (not shown). Even at only $10 \mu \mathrm{M}, \mathrm{CNQX}$ produced a marked reduction in the neuronal injury induced by all 3 agonists. Control experiments verified that no antagonist was intrinsically toxic with the tested exposures.

\section{Selectivity of excitatory amino acid antagonists}

The selectivity of CNQX as an antagonist of excitatory amino acid neurotoxicity was compared with that of the broad spectrum antagonist kynurenate and the NMDA antagonist APV. Cultures were exposed for $24 \mathrm{hr}$ to $30 \mu \mathrm{M}$ NMDA or $30 \mu \mathrm{M}$ kainate, threshold concentrations just sufficient to destroy the majority of the neuronal population in the absence of antagonist (Koh and Choi, 1988b). Addition of CNQX, kynurenate, or 
Figure 5. Pharmacology of nonNMDA receptor-induced acute neuronal swelling. Bars depict the average percentage changes ( \pm SEM, $n=36-80$ cells) in neuronal cell area $20 \mathrm{~min}$ after the indicated toxic exposures in sister cultures. Concentrations are specified in micromolar; sodium replaccment (Na-free) was accomplished with equimolar choline. Asterisk $\left({ }^{*}\right)$ indicates significant difference $(p<0.05)$ compared with the swelling produced by $100 \mu \mathrm{M}$ of the same agonist alone (2-tailed $t$-test with Bonferroni correction for 5 comparisons).

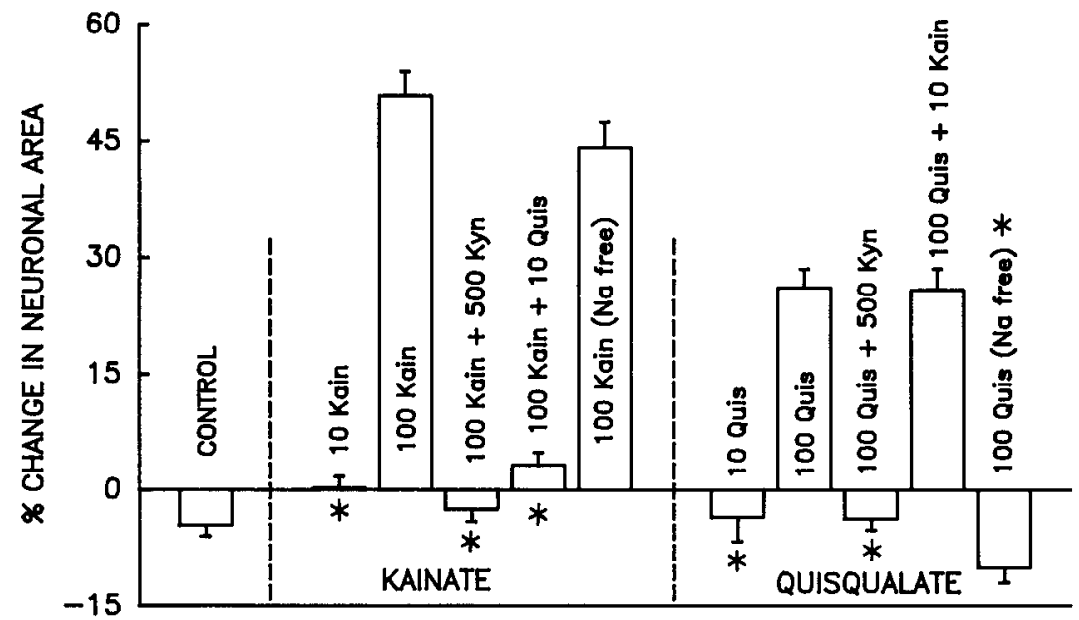

APV to the exposure solution produced antagonist concentration-dependent reductions in resultant neuronal loss (Fig. 8). CNQX was about 100 times more potent than kynurenate in blocking kainate toxicity; $\mathrm{IC}_{50}$ 's against kainate toxicity were about $1 \mu \mathrm{M}$ for CNQX and $100 \mu \mathrm{M}$ for kynurenate. However, CNQX also blocked NMDA toxicity 30 times more potently than kynurenate, and actually as potently as APV (both $\mathrm{IC}_{50}$ 's about $10 \mu \mathrm{M}$ ). The observed selectivity ratio, $\mathrm{IC}_{50}$ against $\mathrm{NMDA}$ $\mathrm{IC}_{50}$ against kainate, for CNQX was thus only 10 , which was 3.3 limes that of kynurenate (Table 1). APV showed a selectivity ratio of less than 0.01 .

\section{Paradoxical neurotoxicity of brief quisqualate exposure}

We considered it puzzling that quisqualate alone could produce widespread neuronal loss after $5 \mathrm{~min}$ exposure and sought to find a basis for this paradoxical toxic efficacy. The finding that quisqualate-induced acute neuronal swelling could be blocked by APV raised the possibility that direct or indirect activation of NMD $\Lambda$ receptors might be responsible. However, the addition of $500 \mu \mathrm{M}$ APV to the exposure solution had little effect on the neurotoxicity associated with brief quisqualate exposure, even if the quisqualate concentration were reduced to only 100 $\mu \mathrm{M}$, a concentration producing submaximal toxicity (Fig. 9). In similar fashion, addition of $500 \mu \mathrm{M}$ concentrations of GAMS, GDEE, kynurenate, or even CNQX to the quisqualate exposure solution also did not affect the toxicity of $5 \mathrm{~min}$ quisqualate exposure (Fig. 9).

Next, we considered the possibility that brief addition of quisqualate somehow induced a lasting stimulation of excitatory amino acid receptors. If either $500 \mu \mathrm{M}$ kynurenate or $10 \mu \mathrm{M}$ CNQX were added to the bathing medium not just during the 5 min quisqualate exposure, but also following quisqualate washout ("continuous" antagonist exposure), marked attenuation of resultant neuronal damage was observed (Fig. 10). APV, GAMS, and GDEE remained ineffective at $500 \mu \mathrm{M}$ (Fig. 10). Similar protection with $10 \mu \mathrm{M}$ CNQX was obtained when the CNQX was added only after the quisqualate washout. These observations suggested that the neurotoxicity of brief quisqualate addition was indeed due to lasting activation of non-NMDA receptors.

One way that this might occur would be if quisqualate were not completely washed out at the end of the 5 min exposure. The standard washout procedure produced a calculated $7000-$ fold dilution of the exposure solution; further increasing washout to a calculated dilution of $>300,000$ did not alter quisqualate toxicity. This washout should be sufficient to remove quisqualate free in the bathing medium. However, simple washout would not remove quisqualate that was either tightly bound to membrane structures or taken up inside cells. Such protected quisqualate might be later released to the extracellular solution, achieving in effect chronic quisqualate exposure. To test this idea, medium was removed from either mixed neuronal and glial cultures or pure glial cultures, $24 \mathrm{hr}$ after $5 \mathrm{~min}$ exposure to quisqualate. Addition of such conditioned medium to other cultures at $1: 3$ dilution resulted in the destruction of the neuronal subpopulation containing the marker enzyme NADPH-diaphorase, a subclass of neurons highly sensitive to non-NMDA receptor-mediated toxicity (Koh and Choi, 1988b) (Fig. 11). Damage to the general neuronal population was less marked. This toxicity of medium removed from cultures previously exposed to quisqualate was not found in cultures similarly exposed to several other excitatory amino acids, even those mixed cultures exposed to glutamate or NMDA where widespread neuronal cell damage had occurred (Fig. 11). Furthermore, HPLC measurements on the media of either mixed or glial cultures subjected $24 \mathrm{hr}$ previously to $5 \mathrm{~min}$ exposure to $0.5-1.0 \mathrm{~mm}$ quisqualate did indeed reveal detectable levels of quisqualate: 2.3 $\pm 0.4 \mu \mathrm{M}(\mathrm{SEM}, n=4)$ in mixed cultures and $1.0 \pm 0.1 \mu \mathrm{M}(n$ $=4$ ) in glial cultures (Fig. 12).

The process responsible for protecting quisqualate from washout might be either tight binding or cellular uptake. Favoring the latter, acute addition of $3 \mathrm{~mm}$ concentrations of 2 compounds known to block glutamate uptake-the chloride transport blocker 4,4'-diisothiocyano-2,2'-disulfonic acid (DIDS) (Bridges et al., 1987; Recasens et al., 1987) and dihydrokainate (DHK) (Johnston et al., 1979)-could attenuate the neuronal damage produced by 5 min quisqualate exposure (Fig. 13).

\section{Zinc potentiation of AMPA neurotoxicity}

Zinc potentiates the neuroexcitatory action of both quisqualate and AMPA (Peters et al., 1987) and increases the neurotoxicity of brief quisqualate exposure (Koh and Choi, 1988c). Addition of $100 \mu \mathrm{M}-1 \mathrm{~mm}$ zinc also produced a concentration-dependent increase in the neuronal injury resulting from a 5 min exposure to $500 \mu \mathrm{M}$ AMPA; the zinc $\mathrm{EC}_{50}$ for this potentiation was about $200 \mu \mathrm{M}$ (Fig. 14). 
Table 1. Comparison of neurotoxicity $\mathrm{IC}_{50} \mathrm{~s}$

\begin{tabular}{|c|c|c|c|}
\hline Drug & vs $30 \mu \mathrm{M}$ Kainate & $\begin{array}{l}\text { vs } 30 \mu \mathrm{M} \\
\text { NMDA }\end{array}$ & $\begin{array}{l}\text { Selectivity } \\
\text { ratio } \\
\text { kainate } \\
\text { over } \\
\text { NMDA }\end{array}$ \\
\hline CNQX & $1 \mu \mathrm{M}$ & $10 \mu \mathrm{M}$ & 10 \\
\hline Kynurenate & $100 \mu \mathrm{M}$ & $300 \mu \mathrm{M}$ & 3 \\
\hline DL-APV & $>1000 \mu \mathrm{M}$ & $10 \mu \mathrm{M}$ & $<0.01$ \\
\hline
\end{tabular}

\section{Discussion}

We present here a quantitative characterization of kainate, quisqualate, and AMPA neurotoxicity in cortical cell cultures. Consistent with prior in vivo and in vitro observations, prolonged exposure (20-24 hr) to all 3 agonists produced extensive neuronal degeneration in a concentration-dependent manner. Quisqualate was the most potent $\left(\mathrm{EC}_{50}\right.$ about $\left.1 \mu \mathrm{M}\right)$, followed by AMPA $\left(\mathrm{EC}_{50}\right.$ about $\left.4 \mu \mathrm{M}\right)$ and kainate $\left(\mathrm{EC}_{50}\right.$ about $\left.20 \mu \mathrm{M}\right)$. The broad spectrum antagonist kynurenate reduced the neurotoxicity of all 3 agonists in a fashion consistent with competitive antagonism. Calculated $p A_{2}$ values were in the range 3.7-4.1, in general agreement with values obtained by electrophysiological study (Kemp et al., 1987).

The novel quinoxaline derivative CNQX (Honoré et al., 1987) was much more potent than kynurenate in attenuating kainate neurotoxicity, but only several-fold more selective; it was still as potent as APV in attenuating NMDA neurotoxicity in our cultures. Precedent for CNQX as an NMDA antagonist is provided by a report that $6 \mu \mathrm{M}$ CNQX could noncompetitively block half the maximum NMDA-induced current in Xenopus oocytes injected with rat brain mRNA (Verdoorn et al., 1988). A possible basis for CNQX antagonism of NMDA receptor activation may be displacement of glycine from its modulatory site on the NMDA receptor complex, a mechanism that may be common to other quinoxalinediones (Birch et al., 1988; but see Drejer et al., 1989). In any case, present observations support the idea that effects of CNQX, especially at concentrations higher than $10 \mu \mathrm{M}$, should not be uncritically attributed to the selective antagonism of non-NMDA receptors.

Further study will also be required to define the exact glutamate receptor subpopulations responsible for mediating the neurotoxicity of the tested agonists. A key question is to what extent AMPA and quisqualate activate the same non-NMDA receptor population as kainate. Present observations provide support for the idea that the AMPA activates receptors which are at least partially distinct from those activated by kainate (Monaghan et al., 1983; Greenamyre et al., 1985; Cotman et al., 1987; Ascher and Nowak, 1988). Although with chronic exposure, AMPA was a slightly more potent neurotoxin than kainate, it was more sensitive than kainate to antagonism by GAMS. In addition, AMPA neither mimicked nor interfered with kainate-induced acute neuronal swelling. Finally, zinc markedly potentiated AMPA neurotoxicity, in a fashion similar to its potentiation of quisqualate toxicity but greater than its potentiation of kainate toxicity (Koh and Choi, 1988c). Pending molecular biological insights, it remains attractive to refer to the receptors activated specifically by AMPA as "AMPA/quisqualate receptors." 'The inability of AMPA/quisqualate receptor activation (by either AMPA or quisqualate + APV) to induce

\section{A}

KYNURENATE VS. QUISQUALATE

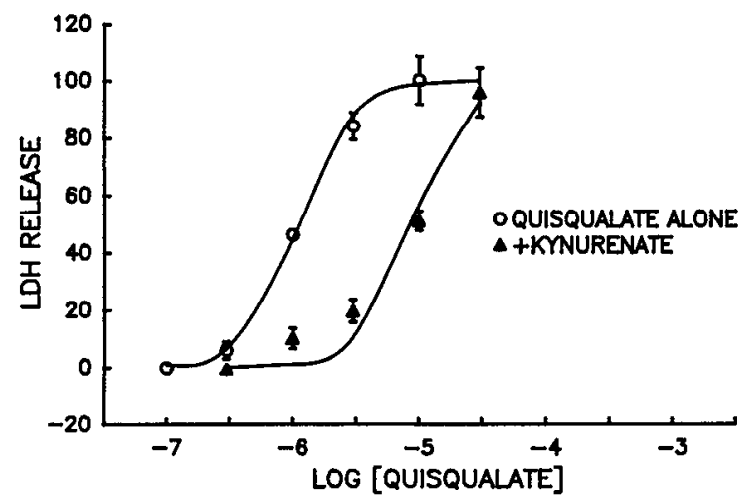

$$
\text { B }
$$

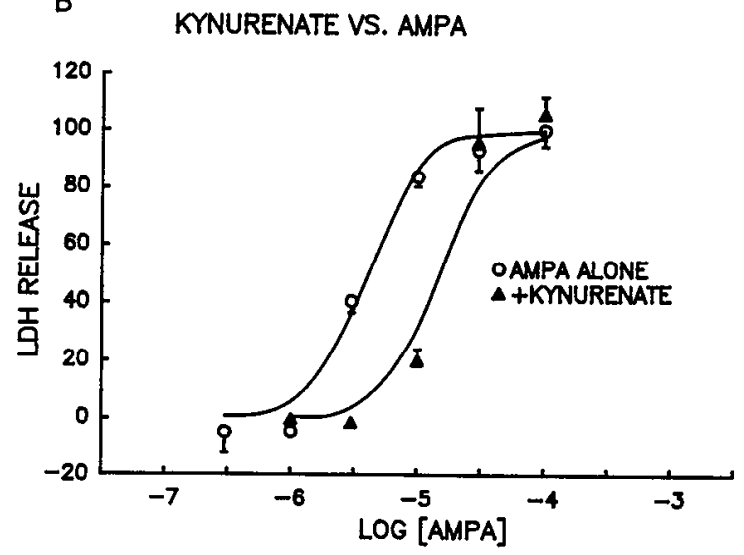

C

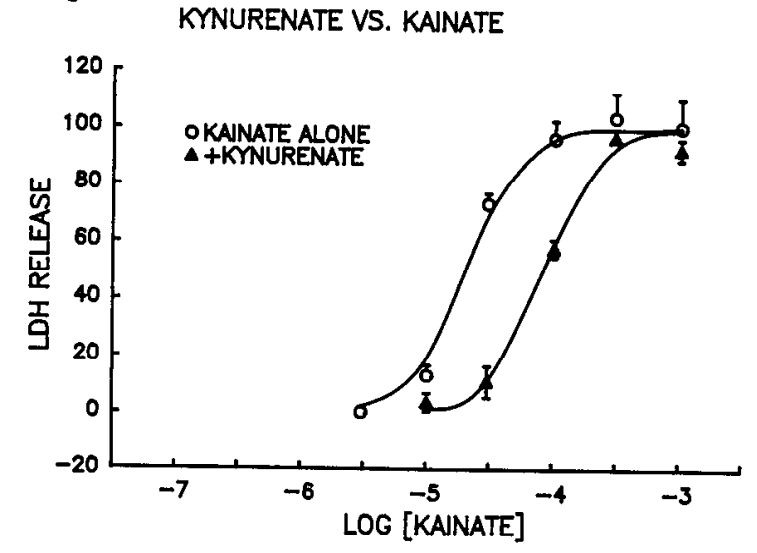

Figure 6. Kynurenate competitively antagonizes the neurotoxicity produced by lengthy exposure to non-NMDA agonists. $A$, Mean LDH $( \pm$ SEM, $n=4)$ in the medium after $24 \mathrm{hr}$ exposure of sister cultures to the indicated concentrations of quisqualate either alone or in the presence of $500 \mu \mathrm{M}$ kynurenate. The toxic $\mathrm{EC}_{50}$ for $24 \mathrm{hr}$ quisqualate exposure alone was about $1 \mu \mathrm{M}$; addition of $500 \mu \mathrm{M}$ kynurenate shifted this concentration-toxicity relationship to the right $\left(\mathrm{EC}_{50}\right.$ about $\left.10 \mu \mathrm{M}\right)$. $\mathrm{LDH}$ values were normalized to the mean $\mathrm{LDH}$ seen in cultures exposed to the highest concentrations of quisqualate alone. $B$, Same as $A$ but with AMPA. EC so $_{50}$ for AMPA alone or with kynurenate was about 4 and $15 \mu \mathrm{M}$, respectively. $C$, Same as $A$ but with kainate. $\mathrm{EC}_{50}$ for kainate alone or with kynurenate was about 20 and $85 \mu \mathrm{M}$, respectively. 
Figure 7. Antagonist pharmacology of non-NMDA neurotoxicity. Bars depict the mean LDH ( + SEM, $n=4)$ released after a $20 \mathrm{hr}$ exposure to the indicated agonists either alone (control) or in the presence of antagonists. All LDH values were scaled to the mean value seen $(=100)$. Asterisk $(*)$ indicates significant difference from control $(p<0.05)$ by 2 -tailed $t$-test and Bonferroni correction for 4 comparisons. into the bathing media in sister cultures in cultures exposed to $30 \mu \mathrm{M}$ kainate

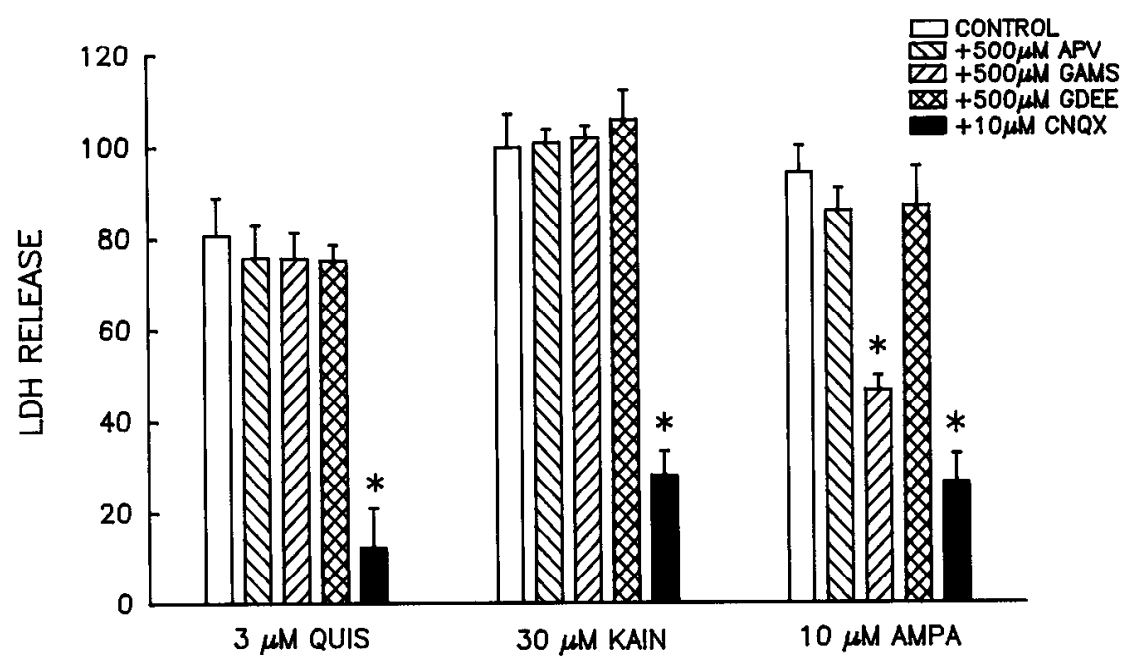

acute neuronal swelling might be accounted for by small number, low conductance of the associated ionophore, or partial descnsitization.

However, these observations cannot exclude the possibility that such an AMPA/quisqualate receptor population overlaps with the kainate receptor population. Indeed, it is likely that quisqualate itself interacts substantially with kainate receptors and NMDA receptors (see below) in addition to AMPA/quisqualate receptors. Quisqualate toxicity was less sensitive to GAMS than was AMPA toxicity. Furthermore, low concentrations $(10 \mu \mathrm{M})$ of quisqualate attenuated kainate-induced swelling. Quisqualate could act as a kainate antagonist because it has higher affinity but only partial agonist properties at kainate receptors (O'Brien and Fischbach, 1986; Gallo et al., 1989). Other mechanisms can also be considered; for example, some quisqualate effects could be mediated by the metabotropic quisqualate receptor (Sladeczek et al., 1985; Nicoletti et al., 1986; Sugiyama et al., 1987).

In contrast to their potency as neurotoxins with prolonged exposure, even millimolar concentrations of kainate or AMPA failed to produce much neuronal cell loss with exposure times under $30 \mathrm{~min}$. This generalization applies only to the cortical neuronal population as a whole; certain small neuronal subpopulations, for example NADPH-diaphorase-containing neurons, may exhibit heightened vulnerability to injury by nonNMDA agonists (Koh and Choi, 1988b). While non-NMDA receptor-mediated neurotoxicity has recently been induced by glutamate exposure on cultured cortical neurons (Frandsen et al., 1989) and young cultured hippocampal neurons (Mattson et al., 1989), both studies utilized lengthy (several hour) exposure durations. It can be noted that the resistance of young ( 5 $\mathrm{d}$ in culture) hippocampal neurons to NMDA receptor-mediated injury (Mattson et al., 1989) is consistent with the resistance of young cortical neurons to injury by brief glutamate exposure (Choi et al., 1987).

Kainate did induce widespread acute "excitotoxic" neuronal swelling. For the most part, this swelling was reversible, consistent with our earlier demonstration that $5 \mathrm{~min}$ exposure to glutamate in the presence of APV is followed by transient neuronal swelling but little late neuronal degeneration (Choi et al., 1988). Another example of a dissociation between acute excitotoxicity and late neuronal degeneration was provided by removing extracellular calcium during toxic glutamate exposure: acute neuronal swelling was increased, but late neuronal cell loss
Figure 8. Comparison of the selectivity of CNQX, kynurenate, and APV. Mean LDH $( \pm$ SEM, $n=4)$ present in the bathing media after exposure of sister cultures to either $30 \mu \mathrm{M}$ kainate or $30 \mu \mathrm{M}$ NMDA $24 \mathrm{hr}$ in the presence of indicated concentrations of CNQX, kynurenate, or APV. Approximate $\mathrm{IC}_{50}$ 's: for CNQX, $1 \mu \mathrm{M}$ against kainate and $10 \mu \mathrm{M}$ against NMDA; for kynurenate, $100 \mu \mathrm{M}$ against kainate and $300 \mu \mathrm{M}$ against NMDA; for APV, >1 mM against kainate and $10 \mu \mathrm{M}$ against NMDA.

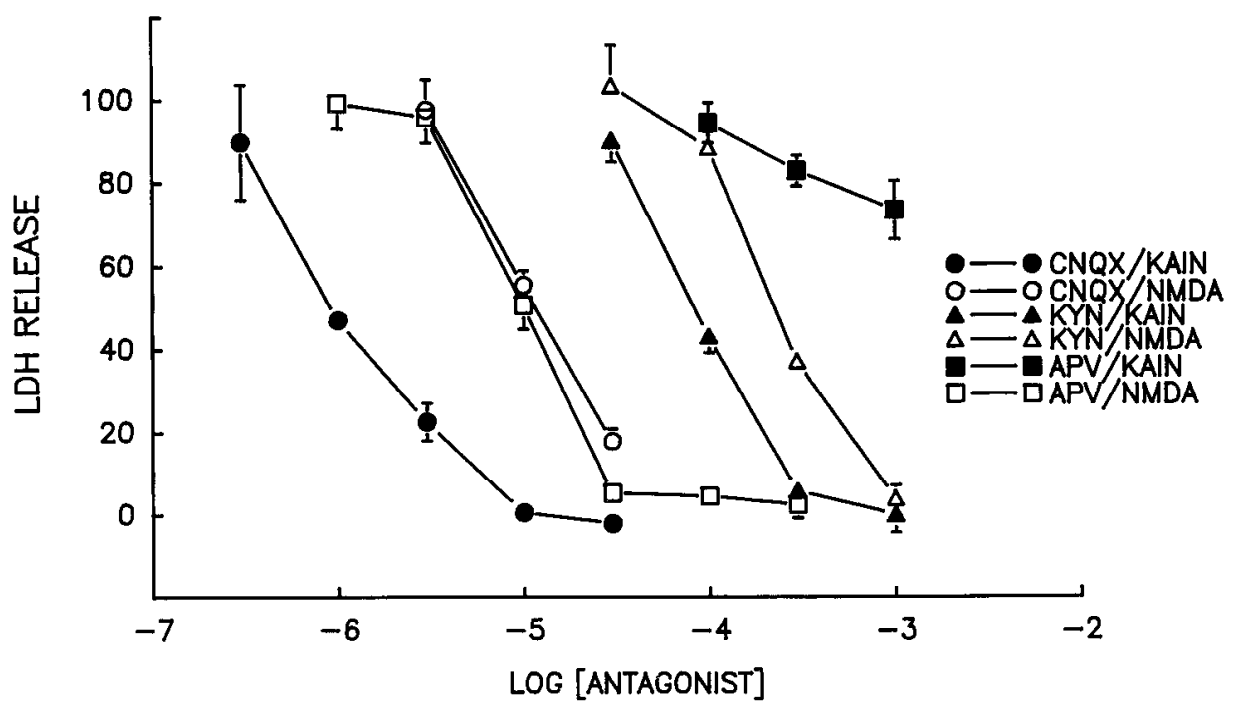




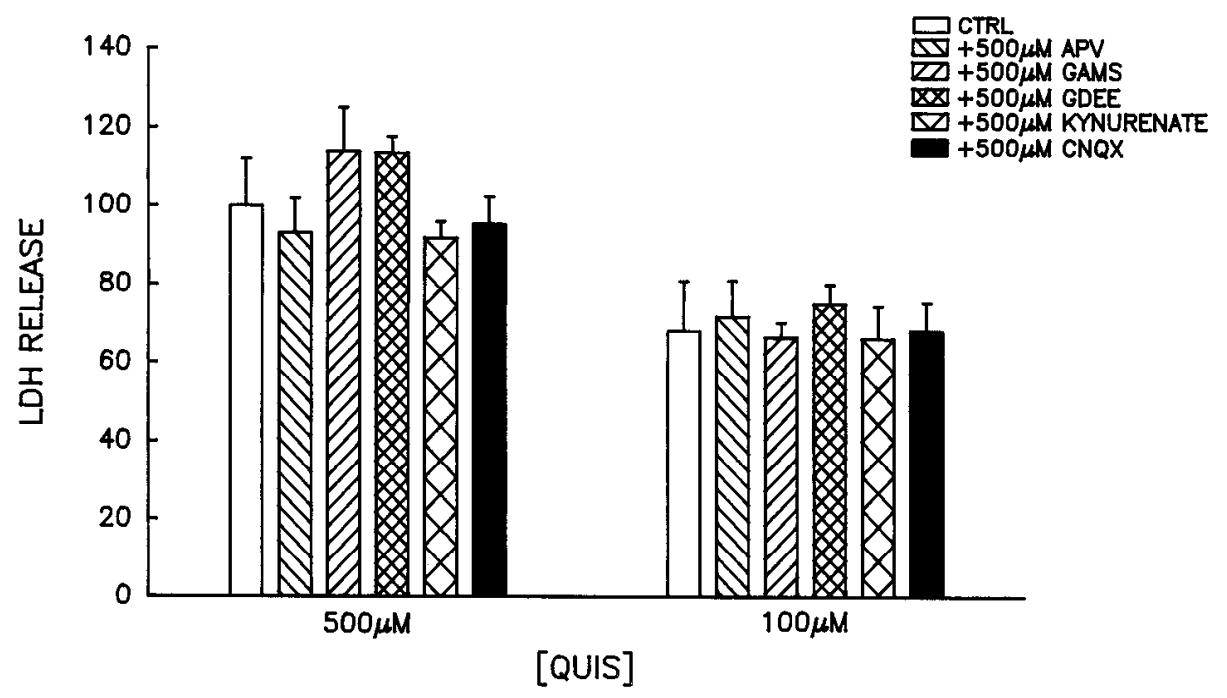

Figure 9. No excitatory amino acid antagonist, when applied during exposure, attenuates the toxicity of brief quisqualate exposure. Left group of bars show mean LDH (+SEM, $n=4)$ present in the medium the following day after $5 \mathrm{~min}$ exposure of sister cultures to $500 \mu \mathrm{M}$ quisqualate either alone $(C T R L)$ or in the presence of the indicated antagonists, added acutely during quisqualate exposure. Right bars depict the same, but with $100 \mu \mathrm{M}$ quisqualate. No antagonist showed significant protective effect ( $p$ for all $>0.3$ by 2 -tailed $t$-test). LDH values were scaled to the mean $\mathrm{LDH}$ in cultures exposed to $500 \mu \mathrm{M}$ quisqualate for $5 \mathrm{~min}$.

was reduced (Choi, 1987). The acute neuronal swelling produced by kainate may be due to a large influx of sodium through kainate-activated channels, followed by influx of chloride and water. Nonetheless, brief activation of kainate or AMPA receptors was much better tolerated by most neurons than similar activation of NMDA receptors. The lesser neuronal degeneration produced by brief non-NMDA receptor activation, compared with NMDA receptor activation, may be partly due to the lower calcium permeability of the channels activated by nonNMDA receptors (MacDermott et al., 1986).

Unlike kainate or AMPA, brief exposure to quisqualate produced both acute neuronal swelling and widespread late neuronal destruction. These quisqualate effects were not explained by glutamate contamination. The measured level of contamination in the quisqualate lot used here $(2 \%)$ was too low to account for either effect, and furthermore, both effects could be produced by synthetic quisqualate lacking measurable glutamate contamination. Instead, data presented here suggest that the neurotoxicity associated with brief quisqualate exposure may be a complex reflection of processes beyond simple transient activation of AMPA/quisqualate or kainate receptors.

The acute swelling produced by quisqualate could be blocked by APV and thus was presumptively mediated by NMDA receptor activation. Most likely, quisqualate at hundred micro- molar concentrations acts directly as a weak agonist at NMDA receptors; binding studies have shown that quisqualate has weak affinity for NMDA receptors (Olverman et al., 1984; Greenamyre et al., 1985), and single-channel recording has shown that quisqualate can open NMDA channels (Ascher and Nowak, 1988). Alternatively, NMDA receptors might be activatcd by glutamate or other endogenous NMDA agonists released from neurons stimulated by quisqualate. In any case, quisqualateinduced activation of NMDA receptors was not the major explanation for the late cell loss induced by brief quisqualate exposure, since the latter was not blocked by APV.

Consistent with the idea that quisqualate produces acute neuronal swelling by activating NMDA receptors, this swelling could be blocked by the substitution of choline for extracellular sodium, a maneuver previously found to block the swelling induced by selective NMDA agonists (Choi et al., 1988). In contrast, the neuronal swelling induced by kainate was not attenuated by the same procedure. It is possible that kainate-gated channels may be permeable to choline, similar to the channels gated by nicotinic ACh receptors (Dwyer et al., 1980). Of note, kainategated channels may be larger in pore size than the channels gated by NMDA (Vyklicky et al., 1988).

Observations here also invoke another process to explain the paradoxical late neuronal loss associated with brief quisqualate

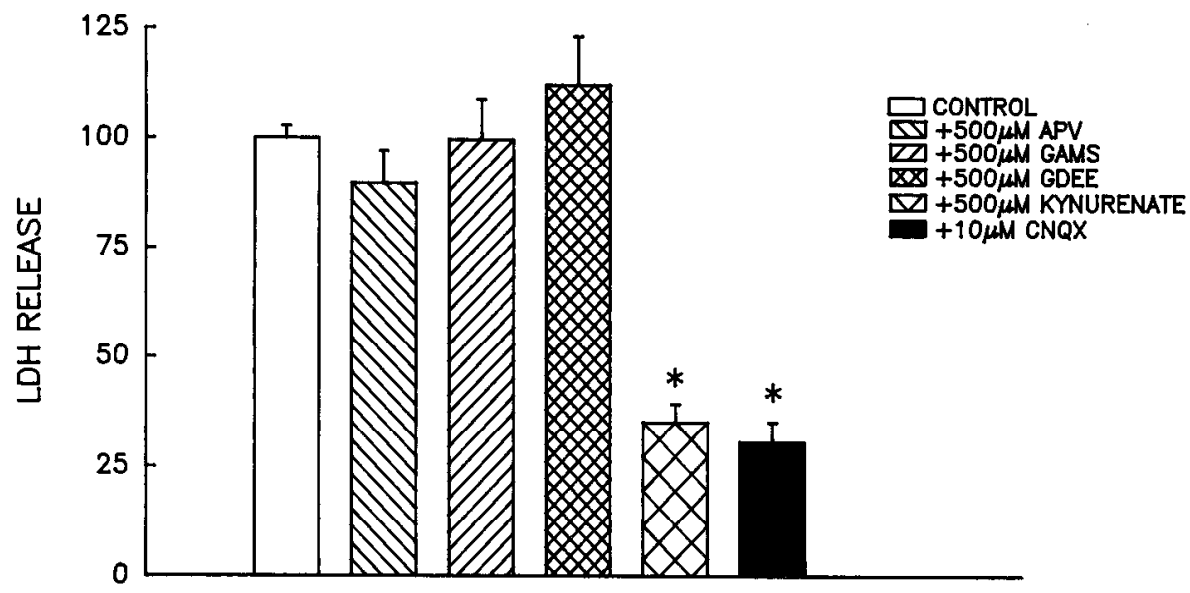

Figure 10. Continuous application of kynurenate or CNQX markedly attenuates the toxicity of brief quisqualate exposure. Bars depict mean LDH $(+\mathrm{SEM}, n=4)$ released in sister cultures after $5 \mathrm{~min}$ exposure to $500 \mu \mathrm{M}$ quisqualate either alone (control) or in the presence of indicated antagonists, added both during and after quisqualate exposure. Asterisk $\left(^{*}\right)$ indicates significant difference $(p<0.05)$ from control by 2 -tailed $t$-test with Bonferroni correction. These results were obtained with natural quisqualate; similar results were obtained with synthetic quisqualate. 
Figure 11. Media of cultures previously exposed to quisqualate can damage NADPH-diaphorase-containing neurons. A sample of the bathing medium was taken $24 \mathrm{hr}$ after exposure of sister mixed or glial cultures to $500 \mu \mathrm{M}$ of indicated agonists for $5 \mathrm{~min}$ and added to other mixed cultures (net dilution, 1:3). Then, $24 \mathrm{hr}$ later, the number of NADPH-diaphorase-containing neurons in each well was counted and the percentage loss of these neurons was determined.

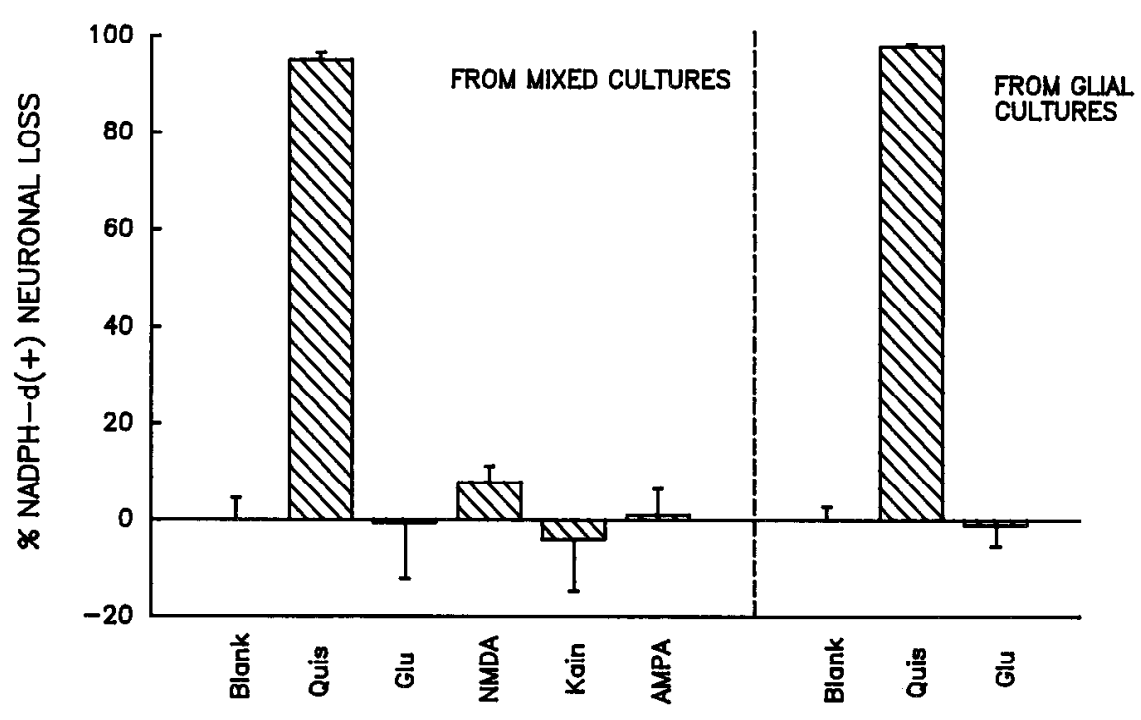

toxicity. We do not think that the validity of the uptake-late release hypothesis is diminished by the failure of the transferred bathing medium to produce generalized neuronal destruction in the test cultures. Quisqualate concentrations reached in the bath of the original cultures would have been 3 -fold higher than in the test cultures due to transfer dilution; furthermore, the actual effective quisqualate concentrations achieved locally near cellular release sites in the original cultures might well have been higher than the concentrations that ultimately accumulated in the bathing medium.

Present observations suggest that both neurons and glia in combination, and glia alone, can participate in such quisqualate uptake and late release. Specifically supporting a rolc for cellular uptake, the acute addition of 2 glutamate uptake inhibitors, DIDS and DHK, attenuated resultant neuronal injury in the brief quisqualate exposure paradigm.

We present in Table 2 a speculative summary of our observations to date with glutamate receptor-mediated injury of cultured cortical neurons. For reasons discussed above, the assumptions are made that AMPA and kainate act on distinct receptors and that the complex effects of quisqualate are ex-
A. A. STANDARDS $(2.5 \mu \mathrm{M})$

Figure 12. HPLC determination of the quisqualate present in the media $24 \mathrm{hr}$ after exposure to either quisqualate or glutamate. After $5 \mathrm{~min}$ exposure to 1 mм quisqualate or glutamate, cultures were thoroughly washed and incubated overnight in culture medium lacking serum. Then, $24 \mathrm{hr}$ later, the bathing medium was analyzed by HPLC. Amino acid standard solution contained 2.5 $\mu \mathrm{M}$ concentrations of both glutamate $(G)$ and quisqualate $(Q)$ (thick arrows). The quisqualate peak (about $3 \mu \mathrm{M}$ in this sample) was found only in the media of cultures previously exposed to quisqualate (Post-Quis) but not in cultures previously exposed to glutamate (Post$G(u)$. Thin arrows indicate the beginning of elution.

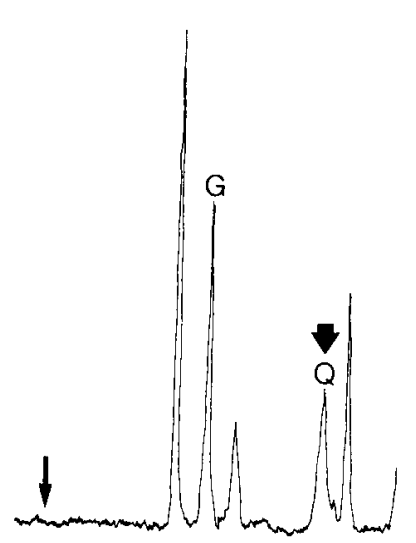

POST-GLU

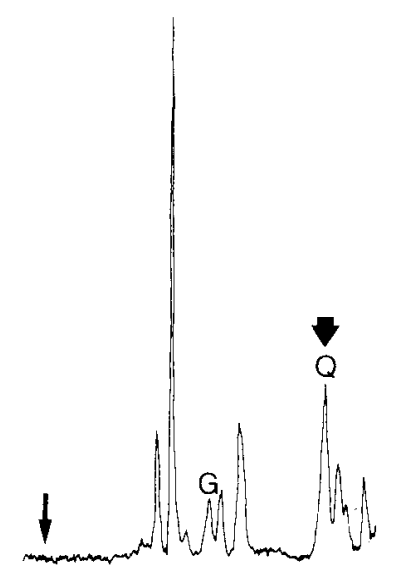

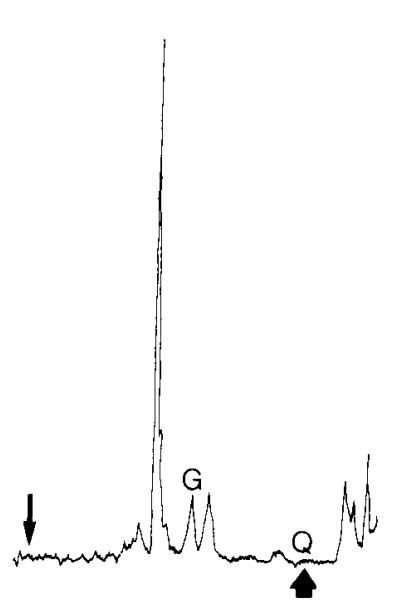




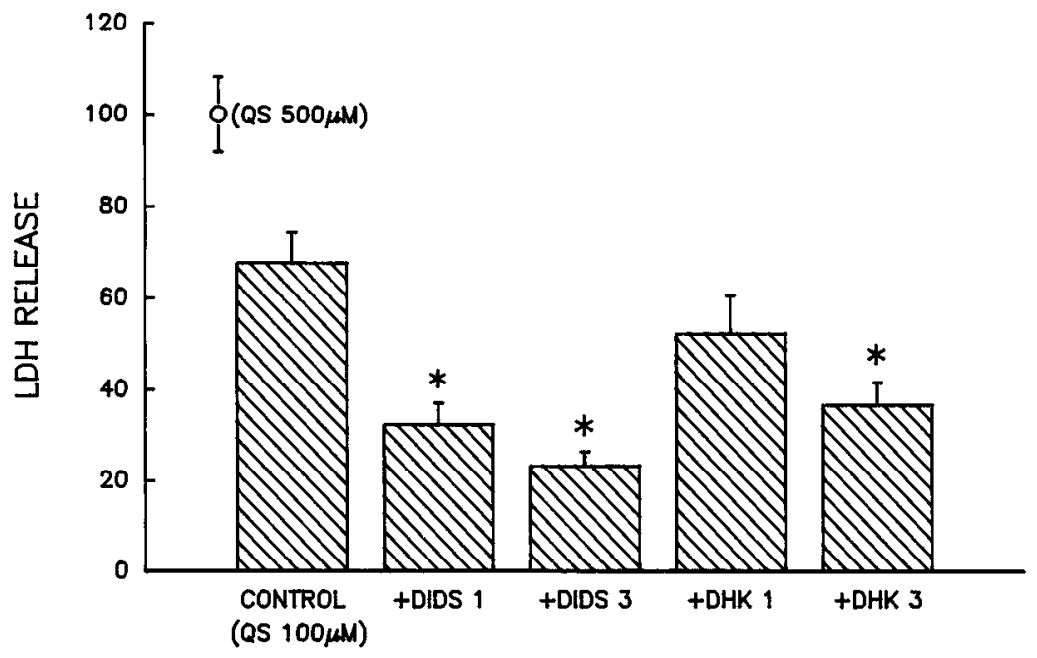

Figure 13. Effect of glutamate uptake inhibitors on the neurotoxicity of brief quisqualate exposure. DIDS or DHK at 1 or $3 \mathrm{mM}$ was applied with $100 \mu \mathrm{M}$ quisqualate for $5 \mathrm{~min}$ to sister cultures. Bars represent mean LDH ( + SEM, $n$ $=4$ ) present in the media $24 \mathrm{hr}$ after exposure, normalized to the mean value in sister cultures exposed to $500 \mu \mathrm{M}$ quisqualate for $5 \mathrm{~min}$. Asterisk (*) indicates significant difference $(p<0.05)$ from quisqualate alone (control) by 2-tailed $t$-test with Bonferonni correction for 4 comparisons. plained by interaction with all 3 glutamate receptor subtypes. As a hypothesis subject to future testing, we propose that the neuronal degeneration induced by prolonged exposure to nonNMDA agonists may be largely mediated by a calcium influx triggered secondarily by sodium influx; e.g., through voltagegated channels, reverse operation of the sodium-calcium exchanger, and/or calcium leak conductance due to cell swelling (Choi, 1987). Calcium dependence of kainate toxicity has been observed in rat cerebellar slices (Garthwaite and Garthwaitc, 1986) and hippocampal cultures (Rothman et al., 1987). Voltage-gated calcium channels may be especially important, as $10-$

Table 2. Summary of neurotoxic properties of glutamate receptors

\begin{tabular}{|c|c|c|c|}
\hline \multirow[b]{2}{*}{ Property } & \multicolumn{3}{|c|}{ Receptor type } \\
\hline & $\begin{array}{l}\text { AMPA/ } \\
\text { quisqua- } \\
\text { late }\end{array}$ & Kainate & NMDA \\
\hline \multicolumn{4}{|l|}{ Neurotoxicity } \\
\hline Acute swelling & - & + & + \\
\hline Swelling in $-\mathrm{Na} /$ choline & & + & - \\
\hline Late death ( 5 min exposure) & - & - & + \\
\hline Late death ( $24 \mathrm{hr}$ exposure) & + & + & + \\
\hline NADPH-d(+) cells vulnerable & + & + & - \\
\hline \multicolumn{4}{|l|}{ Agonists } \\
\hline NMDA & - & - & + \\
\hline Kainate & - & + & - \\
\hline AMPA & + & - & - \\
\hline Quisqualate & + & $\pm^{a}$ & $\pm^{h}$ \\
\hline Glutamate & + & + & + \\
\hline \multicolumn{4}{|l|}{ Antagonists } \\
\hline APV & - & - & + \\
\hline GDEE & - & - & - \\
\hline GAMS & + & \pm & - \\
\hline CNQX & + & + & \pm \\
\hline Kynurenate & + & + & + \\
\hline
\end{tabular}

Table is based on observations presented here and in Choi et al. (1988).

"High-affinity but partial agonism, effective antagonist.

"Weak agonist.
$100 \mu \mathrm{M}$ nifedipine partially reduced the toxicity of $24 \mathrm{hr}$ exposure to either AMPA or kainate in our cortical cultures (Weiss et al., 1989a), and GABA plus diazepam blocked non-NMDA receptor-mediated injury to young hippocampal neurons (Mattson et al., 1989).

The role that non-NMDA receptors may play in disease pathogenesis will be another topic suitable for future exploration. Brief intense activation of non-NMDA receptors appears to be better tolerated than similar activation of NMDA receptors; thus, non-NMDA receptors may be less important than NMDA receptors in the setting of acute brain injury. However, the high potency with which prolonged stimulation of non-NMDA receptors can destroy neurons could be the substrate for important involvement in certain chronic neurodegenerative states.

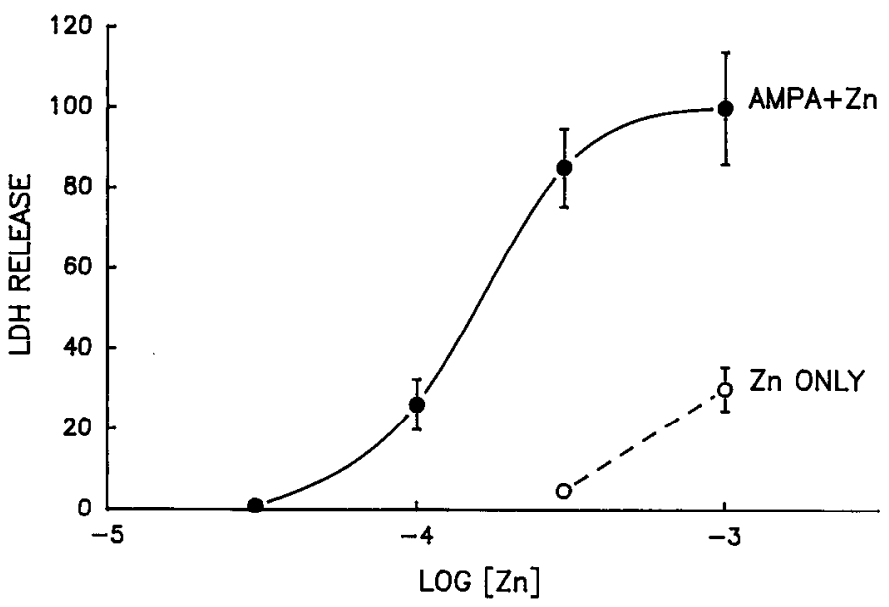

Figure 14. Zinc potentiates acute AMPA neurotoxicity. Sister cultures were exposed for 5 min to $500 \mu \mathrm{m}$ AMPA in the presence of the indicated concentrations of $\mathrm{Zn}^{2+}$ (solid line). Closed circles show mean LDH $( \pm \mathrm{SEM}$, $n=4$ ) present in the media $24 \mathrm{hr}$ after exposure, scaled to the mean value found in the cultures exposed to AMPA in the presence of $1 \mathrm{mM}$ $\mathrm{Zn}^{2+}(=100$, associated with near-complete morphological neuronal destruction). Open circles show the neuronal damage produced by exposure to $\mathrm{Zn}$ alone ( $\pm \mathrm{SEM}, n=4)$. 


\section{References}

Arunlakshana, O., and H. O. Schild (1959) Some quantitative uses of drug antagonists. Br. J. Pharmacol. 14: 48-58.

Ascher, P., and L. Nowak (1988) Quisqualate- and kainate-activated channels in mouse central neurones in culture. J. Physiol. (Lond.) 399: 227-245.

Birch, P. J., C. J. Grossman, and A. G. Hayes (1988) 6,7-Dinitroquinoxaline-2,3-dione and 6-nitro,7-cyano-quinoxaline-2,3-dione antagonise responses to NMDA in the rat spinal cord via an action at the strychnine-insensitive glycine receptor. Eur. J. Pharmacol. 156: 177-180.

Bridges, R. J., M. Nieto-Sampedro, M. Kadri, and C. W. Cotman (1987) A novel chloride-dependent $\mathrm{L}-\left[{ }^{3} \mathrm{H}\right]$-glutamate binding site in astrocyte membranes. J. Neurochem. 48: 1709-1715.

Cha, J. J., J. T. Greenamyre, E. O. Nielsen, J. P. Penney, and A. B. Young (1988) Properties of quisqualate-sensitive L-[3] $\mathrm{H}]$ glutamate binding sites in rat brain as determined by quantitative autoradiography. J. Neurochem. 51: 469-478.

Choi, D. W. (1987) Ionic dependence of glutamate neurotoxicity in cortical cell culturc. J. Neurosci. 7: 369-379.

Choi, D. W. (1988) Glutamate neurotoxicity and diseases of the nervous system. Neuron 1: 623-634.

Choi, D. W. (1989) Non-NMDA receptor-mediated neuronal injury in Alzheimer's disease? Neurobiol. Aging (in press).

Choi, D. W., M. A. Maulucci-Gedde, and A. R. Kriegstein (1987) Glutamate neurotoxicity in cortical cell culture. J. Neurosci. 7: 357368.

Choi, D. W. J. Koh, and S. Peters (1988) Pharmacology of glutamate neurotoxicity in cortical cell culture: Attenuation by NMDA antagonists. J. Neurosci. 8: 185-196.

Connick, J. H., and T. W. Stone (1988) Excitatory amino acid antagonists and endogenous aspartate and glutamate release from rat hippocampal slices. Br. J. Pharmacol. 93: 863-867.

Cotman, C. W., D. T. Monaghan, O. P. Ottersen, and J. Storm-Mathisen (1987) Anatomical organization of excitatory amino acid receptors and their pathways. Trends Neurosci. 10:273-280.

Coyle, J. T., S. J. Bird, R. H. Evans, R. L. Gulley, J. V. Nadler, W. J. Nicklas, and J. W. Olney (1981) Excitatory amino acid neurotoxins: Selectivity, specificity, and mechanisms of action. Neurosci. Res. Prog. Bull. 19: 331-427.

Drejer, J., L. H. Jensen, M. Sheardown, and T. Honoré (1989) A new potent glycine antagonist FG-9067 (MNQX) shows anticonvulsant activities. J. Neurochem. 52: 542 .

Dwyer, T. M., D. J. Adams, and B. Hille (1980) The permeability of the endplate channel to organic cations in frog muscle. J. Gen. Physiol. 75: 469-492.

Eccles, J. C., and P. L. McGeer (1979) Ionotropic and metabotropic neurotransmission. Trends Neurosci. 2: 39-40.

Faden, A. I., and R. P. Simon (1988) A potential role for excitotoxins in the pathophysiology of spinal cord injury. Annu. Rev. Neurol. 23. 623-629.

Foster, A. C., and G. E. Fagg (1984) Acidic amino acid binding sites in mammalian neuronal membranes: Their characteristics and relationship to synaptic receptors. Brain Res. Rev. 7: 103-164.

Frandsen, A., J. Drejer, and A. Schousboe (1989) Direct evidence that excitotoxicity in cultured neurons is mediated via N-methyl-D-aspartate (NMDA) as well as non-NMDA receptors. J. Neurochem. 53: 297-299.

Gallo, V., C. Giovannini, and G. I evi (1989) Quisqualic acid modulates kainate responses in cultured cerebellar granule cells. J. Neurochem. 52: 10-16.

Garthwaite, G., and J. Garthwaite (1986) Neurotoxicity of excitatory amino acid receptor agonists in rat cerebellar slices: Dependence on calcium concentration. Neurosci. Lett. 66: 193-198.

Garthwaite, G., and J. Garthwaite (1989) Quisqualate neurotoxicity: A delayed, CNQX-sensitive process triggered by a CNQX-insensitive mechanism in young rat hippocampal slices. Neurosci. Lett. 99: 113118.

Greenamyre, J. T., and A. B. Young (1989) Excitatory amino acids and Alzheimer's disease. Neurobiol. Aging (in press).

Greenamyre, J. T., J. M. M. Olson, J. B. Penney, and A. B. Young (1985) Autoradiographic characterization of N-methyl-D-aspartatequisqualate- and kainate-sensitive glutamate binding sites. I. Pharmacol. Exp. Ther. 233: 254-263.
Harris, E. W., D. R. Stevens, and C. W. Cotman (1987) Hippocampal cells primed with quisqualate are depolarized by AP4 and AP6, ligands for a putative glutamate uptake site. Brain Res. 418: 361-365. Honoré, T. J. I auridsen, and P. Krogsgaard-Larsen (1982) The binding of $\left[{ }^{3} \mathrm{H}\right]$ AMPA, a structural analogue of glutamic acid, to rat brain membranes. J. Neurochem. 38: 173-178.

Honoré, T., S. N. Davies, J. Drejer, E. J. Fletcher, P. Jacobsen, D. Lodge, and F. E. Nielsen (1987) Potent and competitive antagonism at non-NMDA receptors by FG 9041 and FG 9065. Soc. Neurosci. Absti. 13: 383.

Johnston, G. A. R., S. M. E. Kennedy, and B. Twitchin (1979) Action of neurotoxin kainic acid on high affinity uptake of L-glutamic acid in rat brain slices. J. Neurochem. 32: 121-127.

Kemp, J. A., S. Grimwood, and A. C. Foster (1987) Characterization of the antagonism of excitatory amino acid receptors in rat cortex by kynurenic acid. Br. J. Pharmacol. 91: 314.

Koh, J., and D. W. Choi (1987) Quantitative determination of glutamate mediated cortical neuronal injury in cell culture by lactate dehydrogenase efflux assay. J. Neurosci. Methods 20: 83-90.

Koh, J., and D. W. Choi (1988a) Cultured striatal neurons containing NADPH-diaphorase or acetylcholinesterase are selectively resistant to injury by NMDA receptor agonists. Brain Res. 446: 374-378.

Koh, J., and D. W. Choi (1988b) Vulnerability of cultured cortical neurons to damage by excitoloxins: Differential susceptibility of neurons containing NADPH-diaphorase. J. Neurosci. 8: 2153-2163.

Koh, J., and D. W. Choi (1988c) Zinc alters excitatory amino acid neurotoxicity on cortical neurons. J. Neurosci. 8: 2164-2171.

Koh, J., S. Peters, and D. W. Choi (1986) Neurons containing NADPHdiaphorase are selectively resistant to quinolinate toxicity. Science 234: 73-76.

Koh, J., D. M. Hartley, and D. W. Choi (1988) Non-NMDA receptormediated neurotoxicity in cortical cultures. Soc. Neurosci. Abstr. 14: 746.

Krogsgaard-Larsen, P., T. Honoré, J. J. Hansen, D. R. Curtis, and D. Lodge (1980) New class of glutamate agonist structurally related to ibotenic acid. Nature 284: 64-66.

Lindroth, P., and K. Mopper (1979) High performance liquid chronatographic determination of amino acids in the picomole range. Anal. Chem. 51: 1667.

Lodge, D., D. R. Curtis, G. A. R. Johnston, and J. C. Bornstein (1980) In vivo inactivation of quisqualate: Studies in the cat spinal cord. Brain Res. 182: 491-495.

MacDermott, A. B., M. L. Mayer, G. L. Westbrook, S. J. Smith, and J. L. Barker (1986) NMDA-receptor activation increases cytoplasmic calcium concentration in cultured spinal cord neurones. Nature 321: $519-522$

MacDonald, J. F., and M. E. Morris (1984) Lathyrus excitotoxin: Mechanism of neuronal excitation by L-2-oxalylamino-3-amino-and L-3-oxalylamino-2-amino-propionic acid. Exp. Brain Res. 57: 158166.

Mattson, M. P., P. B. Guthrie, B. C. Hayes, and S. B. Kater (1989) Roles for mitotic history in the generation and degeneration of hippocampal neuroarchitecture. J. Neurosci. 9: 1223-1232.

Mayer, M. L., and G. L. Westbrook (1987) The physiology of excitatory amino acids in the vertebrate central nervous system. Prog. Neurobiol. 28: 197-276.

Monaghan, D. T., V. R. Holets, D. W. Toy, and C. W. Cotman (1983) Anatomical distributions of four pharmacologically distinct ${ }^{3} \mathrm{H}-\mathrm{L}-$ glutamate binding sites. Nature 306: 176-179.

Nicoletti, F., J. T. Wroblewski, A. Novelli, H. Alho, A. Guidotti, and E. Costa (1986) The activation of inositol phospholipid metabolism as a signal-transducing system for excitatory amino acids in primary cultures of cerebellar granule cells. J. Neurosci. 6: 1905-1911.

O'Brien, R. J., and G. D. Fischbach (1986) Characterization of excitatory amino acid receptors expressed by embryonic chick motor neurons in vitro. J. Neurusci. 6: 3275-3283.

Olney, J. W., C. H. Misra, and V. Rhee (1976) Brain and retinal damage from lathyrus excitotoxin, beta- $\mathrm{N}$-oxalyl-L-alpha, beta-diaminopropionic acid. Nature 264: 659-661.

Olverman, H. J., A. W. Jones, and J. C. Watkins (1984) L-Glutamate has higher affinity than other amino acids for $\left[{ }^{3} \mathrm{H}\right]-\mathrm{D}-\mathrm{AP} 5$ binding sites in rat brain membranes. Nature 307: 460-462.

Peters, S., J. Koh, and D. W. Choi (1987) Zinc selectively blocks the action of $N$-methyl-D-aspartate on cortical neurons. Science $236: 589-$ 593. 
Recasens, R. M., J. P. Pin, and J. Bockaert (1987) Chloride transport blockers inhibit the chloride-dependent glutamate binding to rat brain membrane. Neurosci. Lett. 74: 211-216.

Rothman, S. M., and J. W. Olney (1987) Excitotoxicity and NMDA receptor. Trends Neurosci. 10: 299-302.

Rothman, S. M., J. H. Thurston, and R. E. Hauhart (1987) Delayed neurotoxicity of excitatory amino acids in vitro. Neuroscience 22 : $471-480$.

Scherer-Singler, U., S. R. Vincent, H. Kimura, and E. G. McGeer (1983) Demonstration of a unique population of neurons with NADPHdiaphorase histochemistry. J. Neurosci. Methods 9: 229-234.

Simon, R. P., J. H. Swan, T. Griffiths, and B. S. Meldrum (1984) Blockade of $N$-methyl-D-aspartate receptors may protect against ischemic damage in the brain. Science 226: 850-852.

Sladeczck, F., J. P. Pin, M. Recasens, J. Bockaert, and S. Weiss (1985) Glutamate stimulates inositol phosphate formation in striatal neurones. Nature 317: 717-719.

Spencer, P. S., A. Ludolph, M. P. Dwivedi, D. N. Roy, J. Hugon, and H. H. Schaumburg (1986) Lathyrism: Evidence for role of the neuroexcitatory amino acid BOAA. Lancet 2 : 1066-1067.

Spencer, P. S., P. B. Nunn, J. Hugon, A. C. Ludolph, S. M. Ross, D. N. Roy, and R. C. Robertson (1987) Guam amyotrophic lateral sclerosis-parkinsonism-dementia linked to a plant excitant neurotoxin. Science 237: 517-522.
Sugiyama, H., I. Ito, and C. Hirono (1987) $\Lambda$ new type of glutamate receptor linked to inositol phospholipid metabolism. Nature 325: 531-533.

Verdoorn, T. A., N. W. Kleckner, and R. Dingledine (1988) Rat brain $N$-methyl-D-aspartate receptors expressed in Xenopus oocytes. Science 238: 1114-1116.

Vyklicky, L., J. Krusek, and C. Edward (1988) Differences in pore sizes of the $N$-methyl-D-aspartate and kainate cation channels. Neurosci. Lett. 89: 313-318.

Watkins, J. C., and H. J. Olverman (1987) Agonists and antagonists for excitatory amino acid receptors. Trends Neurosci. 10: 265-272.

Weiss, J. H., M. P. Goldberg, and D. W. Choi (1986) Ketamine protects cultured neocortical neurons from hypoxic injury. Brain Res. 380: $186-190$

Weiss, J. H., J. Koh, and D. W. Choi (1989a) Nifedipine attenuates AMPA or kainate neurotoxicity. Soc. Neurosci. Abstr. 15: 480.

Weiss, J. H., J. Koh, and D. W. Choi (1989b) Neurotoxicity of beta$\mathrm{N}$-methylamino-L-alanine (BMAA) and beta- $\mathrm{N}$-oxalylamino-L-alanine (BOAA) on cultured cortical neurons. Brain Res. 497: 64-71.

Wieloch, T. (1985) Hypoglycemia-induced neuronal damage prevented by an $N$-methyl-D-aspartate antagonist. Science 230:681-683. 